\title{
Variabilitas Genetik Kupu-Kupu Endemik Pulau Halmahera Ornithoptera croesus lydius Berbasis Data Molekuler PCR-RAPD
}

\author{
ABDU MAS'UD ${ }^{1}$, ABUBAKAR ABDULLAH $^{1}$, CHUMIDACH ROINI $^{1}$ \\ ${ }^{1}$ Prodi Pendidikan Biologi FKIP Universitas Khairun Ternate \\ Jl. Pertamina Kampus II Gambesi, Ternate Selatan, Ternate. Maluku Utara. 97719 \\ Email: masudabdu.unk05@gmail.com
}

Received 23 January 2018; Received in revised form 29 January 2018;

Accepted 6 February 2018; Available online 9 May 2018

\begin{abstract}
Ornithoptera croesus lydius is one of the endemic butterflies in Halmahera island, North Maluku. This macrolepidoteran species has interesting body color in male and female butterflies. At $O$. croesus lydius male and female butterfly have variation morphology size and colour body. The genetic variability on the $O$. croesus lydius butterflies is level intraspecies variability. The objective of the research was to understand the genetic variability on the O. croesus lydius based on PCRRAPD marker. The most value of genetic distance is 0,783 on $O$. croesus lydius male and female from hotspot at $780 \mathrm{~m}$ asl. The percentage of polimorphic is $71,95 \%$. Base on similarity value and polymorphic percentage show genetic variability on intraspecies level of the $O$. croesus lydius.
\end{abstract}

Keywords: genetic variation, Ornithoptera croesus lydius, PCR-RAPD

\section{INTISARI}

Ornithoptera croesus lydius merupakan kupu-kupu endemik di pulau Halmahera Maluku Utara. Makrolepidotera ini memiliki warna tubuh yang menarik baik pada kupu-kupu jantan maupun betina. Pada O.croesus lydius jantan dan betina terdapat variasi morfologi ukuran dan warna tubuh. Variasi genetik pada kupu-kupu O. croesus lydius ini merupakan jenis variasi intraspesies. Penelitian ini bertujuan untuk menganalisis variasi genetik pada kupu-kupu endemik di pulau Halmahera $O$. croesus lydius berdasarkan variasi karakter molekuler dengan teknik PCRRAPD. Kesamaan matrik (jarak genetik) terbesar adalah 0,783 pada $O$. croesus lydius jantan dan betina dari hotspot pada ketinggian $780 \mathrm{~m}$ dpl. Hasil studi ini juga menunjukkan bahwa persentase polimorfisme (pola pita) sebesar $71,95 \%$. Nilai similaritas dan persentase polimorfisme tersebut mengindikasikan adanya variasi genetik pada tingkat intraspesies $O$. croesus lydius.

Kata kunci: variasi genetik, Ornithoptera croesus lydius, PCR-RAPD

\section{PENDAHULUAN}

Ornithoptera croesus lydius merupakan salah satu kupu-kupu endemik terindah di pulau Halmahera Maluku Utara. O. croesus lydius ditemukan oleh Felder \& Felder pada tahun 1865 (Collins dan Morris, 1987; Peggie, 2011). Kupu-kupu O. croesus lydius dapat ditemukan di kawasan gunung pasir Jailolo pulau Halmahera Barat Maluku Utara sebagai relung ekologinya (Collins \& Morris, 1985). Secara geografis pulau Halmahera merupakan pulau terbesar di propinsi Maluku Utara dan memiliki potensi keanekaragaman hayati yang tinggi. Karakteristik hotspot $O$. croesus lydius seperti jenis Ornithoptera yang lainnya yaitu adanya tanaman Mussaenda dan Asoka yang merupakan jenis makanan Ornithoptera spp (Mas'ud, 2016).

Variasi morfologi kupu-kupu $O$. croesus lydius jantan dan betina dewasa antara lain: variasi panjang tubuh, panjang sayap, panjang kaki, panjang antena dan warna tubuh serta pola warna sayap. Collins dan Morris, (1987) mendeskripsikan ukuran lebar sayap $O$. croesus lydius betina dewasa adalah 17-20 cm. Peggie (2011) menyatakan bahwa $O$. croesus lydius jantan dewasa memiliki rentang sayap 13,0-15,5 cm dan panjang 
sayap depan 7,5-9,7 cm. Pada O. croesus lydius betina dewasa memiliki bentang sayap 14,5-19,0 cm dan panjang sayap depan 9,6$11,3 \mathrm{~cm}$. Umumnya $O$. croesus lydius jantan memiliki warna tubuh hitam dengan beberapa warna kuning sayap bagian bawah dan warna hijau di sayap depan serta sayap belakang bagian atas, sedangkan $O$. croesus lydius betina memiliki warna tubuh hitam cerah.

Beberapa penelitian melaporkan bahwa Troides spp. dan Ornithoptera spp. memiliki nenek moyang yang sama dan terspesiasi baik di wilayah yang mencakup Australia dan Papua New Guinea atau di bagian Asia Tenggara (Wallace, 1986; Peggi, 2005). Prakash $d k k$ (2007) melaporkan adanya keanekaragaman genetik pada kupu-kupu pada berbagai gradien ketinggian di India barat.

Keanekaragaman kupu-kupu dapat dianalisis menggunakan data morfologi (Herna'ndez. dkk, 2010) atau data molekuler (Sharma $d k k$,2010; Tiple $d k k, 2010$; Zothansangi $d k k, 2011)$. Penggunaan teknik penanda molekuler PCR-RAPD dapat digunakan dalam menganalisis polimorfisme DNA, aliran gen antara populasi, evaluasi struktur populasi genetik, penentuan hubungan genetik, dan filogenetik (Zulfahmi, 2013). Diversitas genetik kupu-kupu baik antarspesies maupun intraspesies dapat dianalisis menggunakan penanda morfologi dan molekuler PCR-RAPD (Yuwono, 2005). Penelitian ini bertujuan untuk menganalisis variabilitas genetik pada kupu-kupu endemik pulau Halmahera O. croesus lydius pada berbagai hotspot di pulau Halmahera barat sebagai basis data konservasi sumber daya genetik lokal kupu-kupu endemik berdasarkan karakter molekuler dengan menggunakan teknik PCR-RAPD.

\section{METODE}

Penelitian ini dilaksanakan pada bulan Juli-Agustus 2016 dan metode pengambilan sampel yang digunakan adalah purposive sampling dengan teknik pengambilan sampel yang digunakan adalah teknik jelajah bebas (Leather, 2005).

Studi Area. Pengambilan kupu-kupu O. croesus lydius dilakukan di tiga lokasi ketinggian tempat (ketinggian $240 \mathrm{~m}$ dpl, 460 $\mathrm{m}$ dpl, dan $780 \mathrm{~m} \mathrm{dpl)}$ di kawasan gunung pasir Jailolo Kabupaten Halmahera Barat. Peta sebaran O. croesus lydius (Gambar 1).

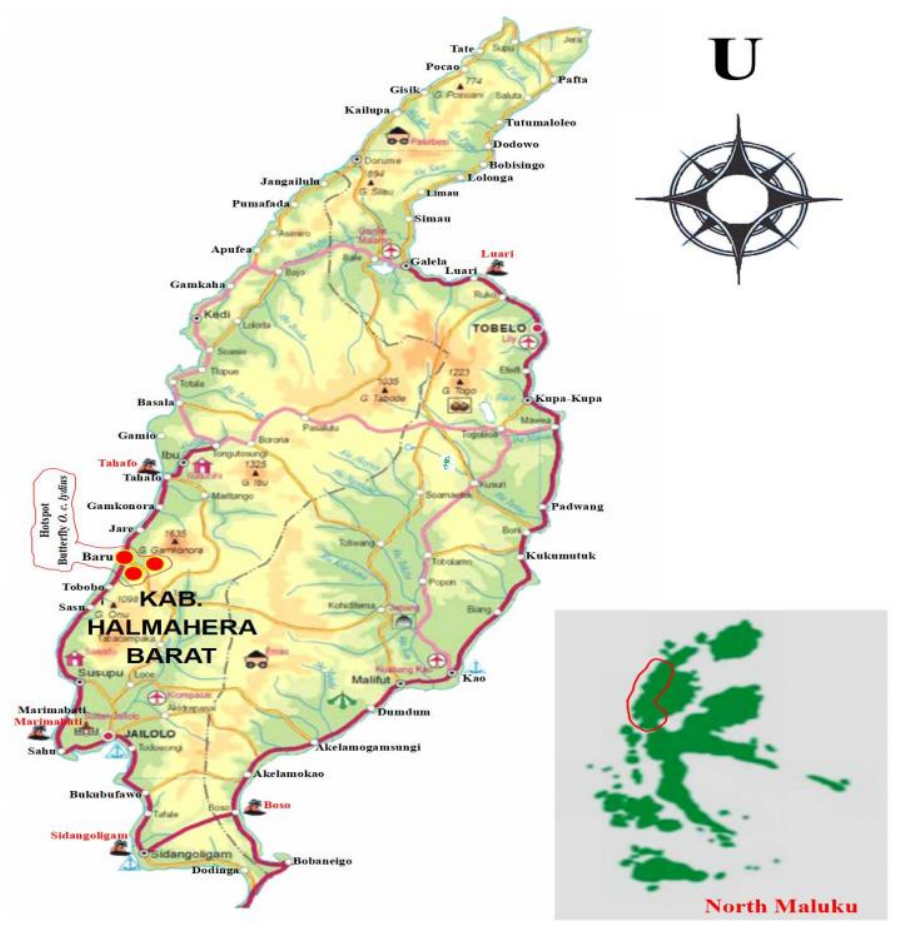

Gambar 1. Lokasi habitat/hospot $O$. croesus lydius di kawasan gunung Pasir Desa Baru Jailolo Halmahera Barat. 
Koleksi Spesimen. O. croesus lydius diawetkan dengan menggunakan kapur barus dan akohol 70\%. Analisis karakter molekuler dengan teknik PCR RAPD dilakukan di Laboratorium Biologi Molekuler dan Seluler Universitas Brawijaya dengan sampel sebanyak 3 individu jantan dan 3 individu betina (Gambar 2). DNA di isolasi menggunakan miniprep kit DNA merk Intron. Amplifikasi DNA pada kondisi Pradenaturasi pada suhu $92^{\circ} \mathrm{C}$ selama 4 menit, denaturasi pada suhu $92^{0} \mathrm{C}$ selama 2 menit, annealing pada suhu $36^{0} \mathrm{C}$ selama 1 menit 30 detik, ekstensi pada suhu $72^{0} \mathrm{C}$ selama 2 menit dan pos ekstensi pada suhu $72^{0} \mathrm{C}$ selama 10 menit sebanyak 45 siklus dilakukan dengan menggunakan PCR merk Takara dengan menggunakan primer OPA 1 sampai OPA 10 (tabel 1). Data dianalisis secara deskriptif kuantitatif dengan menggunakan analisis cluster UPGMA (Unweight Pair Group Method with Aritmathic Mean), dengan menggunakan program Multivariate Statistical Package (MVSP) 3.22 (Kovach, 2007).

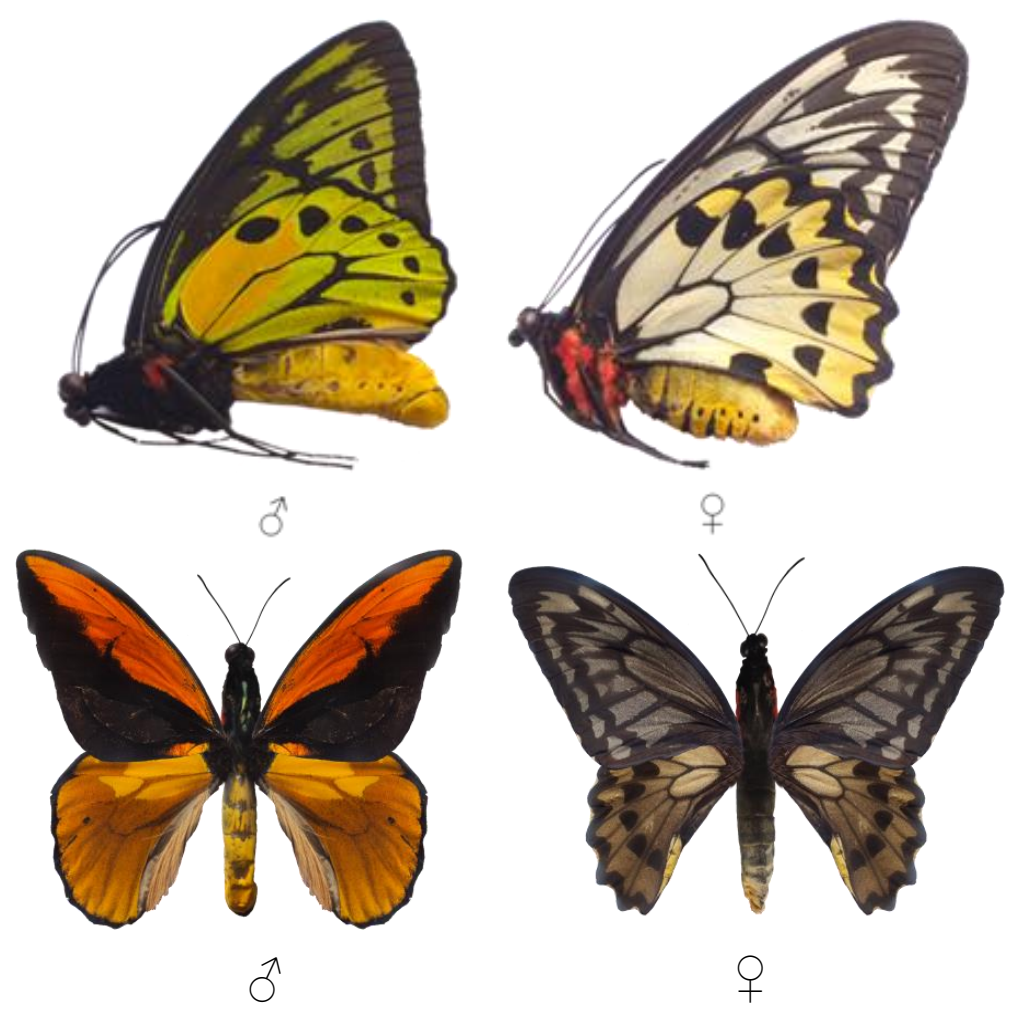

Gambar 2. Spesiesi O.croesus lydius Kupu-Kupu Endemik pulau Halmahera

\section{HASIL}

Data penelitian ini merupakan data analisis molekuler dengan teknik PCR-RAPD berupa perhitungan kemunculan pita DNA (band) O. croesus lydius (Tabel 1). Total pita yang dihasilkan sebanyak 60 pita dengan kriteria 46 polimorfik dan 14 monomorfik, hasil ini dilihat dari pola pita DNA yang muncul pada foto DNA. Rata-rata persentase polimorfisme (pola pita) adalah 71,795\%, pada primer OPA 1-10 (Tabel 1). Selanjutnya dilakukan analisis kesamaan matrik berdasarkan pola kemunculan pita DNA (profil DNA) dengan skoring 1 untuk pita DNA yang muncul dan skoring 0 untuk pita DNA yang tidak muncul disetiap primer OPA 1-10 (Gambar 3). 

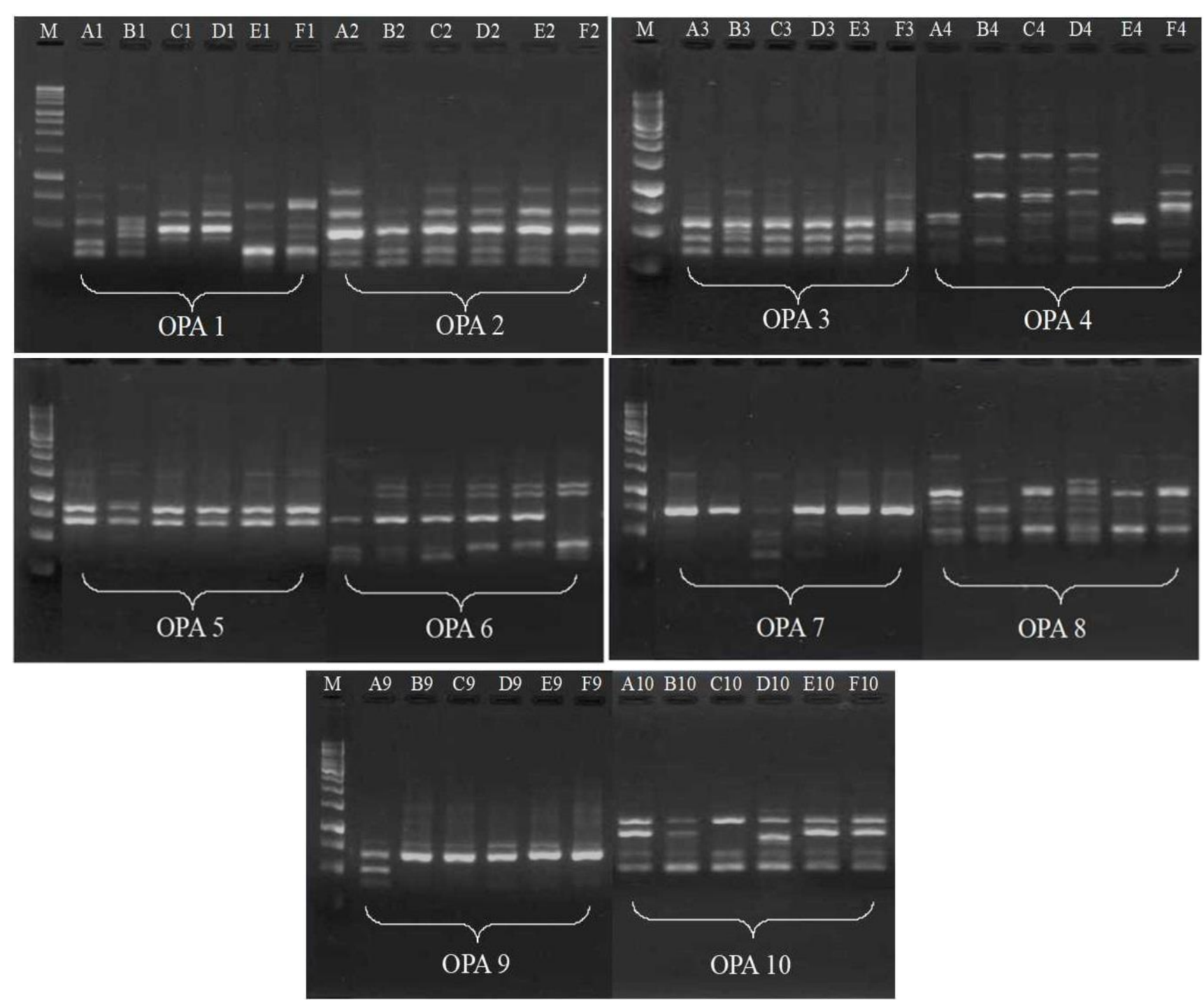

Gambar 3. Visualisasi pola pita 6 individu O. croesus lydius dengan primer OPA 1-10

Tabel 1. Data urutan primer RAPD dan persentase polimorfisme $O$. croesus lydius berdasarkan kehadiran pola pita DNA dianalisis dengan metode UPGMA

\begin{tabular}{cccccc}
\hline Primer & Seq 5 to 3 & $\begin{array}{c}\text { Seq } 5 \text { to 3 } \\
\text { bands }\end{array}$ & $\begin{array}{c}\text { Polymorphic } \\
\text { bands }\end{array}$ & $\begin{array}{c}\text { Monomorphic } \\
\text { bands }\end{array}$ & $\begin{array}{c}\text { Polymorphism } \\
(\%)\end{array}$ \\
\hline OPA-1 & CAG GCC CTT C & 7 & 6 & 1 & 85,71 \\
\hline OPA-2 & TGC CGA GCT G & 6 & 5 & 1 & 83,33 \\
\hline OPA-3 & AGT CAG CCA C & 7 & 5 & 2 & 71,42 \\
\hline OPA-4 & AAT CGG GCT G & 8 & 8 & 0 & 100 \\
\hline OPA-5 & AGG GGT CTT G & 3 & 1 & 2 & 33,33 \\
\hline OPA-6 & GGT CCC TGA C & 6 & 5 & 1 & 83,33 \\
\hline OPA-7 & GAA ACG GGT G & 6 & 5 & 1 & 83,33 \\
\hline OPA-8 & GTG ACG TAG G & 8 & 7 & 2 & 57,50 \\
\hline OPA-9 & GGG TAA CGC C & 4 & 2 & 3 & 40 \\
\hline OPA-10 & GTG ATC GCA G & 5 & 2 & $\mathbf{1 4}$ & $\mathbf{7 1 , 7 9 5}$ \\
\hline Total & & $\mathbf{6 0}$ & $\mathbf{4 6}$ & &
\end{tabular}

Hasil perhitungan kemunculan pita DNA dari visualisasi profil pita DNA (Gambar 3) maka dapat dianalisis kesamaan matrik O. croesus lydius dengan metode UPGMA (Tabel 2). 
Tabel 2. Kesamaan Matriks O.croesus lydius Berdasarkan Kehadiran Pola Pita DNA dianalisis dengan Metode UPGMA

\begin{tabular}{|c|c|c|c|c|c|c|}
\hline & $\begin{array}{c}\text { O.croesus } \\
\text { lydius §ิ } 240 \\
\text { mdpl }\end{array}$ & $\begin{array}{c}\text { O.croesus } \\
\text { lydius } \bigcirc 240 \\
\text { mdpl }\end{array}$ & $\begin{array}{c}\text { O.croesus } \\
\text { lydius §ิ } 460 \\
\text { mdpl }\end{array}$ & $\begin{array}{c}\text { O.croesus } \\
\text { lydius } \propto 460 \\
\text { mdpl }\end{array}$ & $\begin{array}{l}\text { O.croesus } \\
\text { lydius } \widehat{0} \\
780 \mathrm{mdpl}\end{array}$ & $\begin{array}{l}\text { O.croesus } \\
\text { lydius }+ \\
780 \mathrm{mdpl}\end{array}$ \\
\hline $\begin{array}{l}\text { O.croesus lydius } \\
240 \mathrm{mdpl}\end{array}$ & 1 & & & & & \\
\hline $\begin{array}{lll}\text { O.croesus lydius } & \text { } \\
240 \mathrm{mdpl} & & \\
\end{array}$ & 0,583 & 1 & & & & \\
\hline $\begin{array}{l}\text { O.croesus lydius } \sigma^{\pi} \\
460 \mathrm{mdpl}\end{array}$ & 0,583 & 0,667 & 1 & & & \\
\hline $\begin{array}{lll}\text { O.croesus lydius } & \text { + } \\
460 \mathrm{mdpl} & & \\
\end{array}$ & 0,617 & 0,7 & 0,767 & 1 & & \\
\hline $\begin{array}{lll}\text { O.croesus lydius } \\
780 \mathrm{mdpl}\end{array}$ & 0,683 & 0,633 & 0,733 & 0,733 & 1 & \\
\hline $\begin{array}{lll}\text { O.croesus lydius } & \text { 인 } \\
780 \mathrm{mdpl} & & \\
\end{array}$ & 0,667 & 0,683 & 0,65 & 0,683 & 0,783 & 1 \\
\hline
\end{tabular}

Nilai kesamaan matrik (Tabel 2) tertinggi adalah 0,783 pada $O$. croesus lydius $\widehat{O} 780 \mathrm{~m}$ dpl dan $O$. croesus lydius $9780 \mathrm{~m}$ dpl. Nilai kesamaan matrik terendah adalah 0,583 pada O. croesus lydius $\curvearrowright 240 \mathrm{~m}$ dpl dan O. croesus lydius $+460 \mathrm{~m}$ dpl. Nilai kesamaan matrik yang tinggi menunjukkan banyak kemiripan pada kupu O. croesus lydius tersebut dan sebaliknya.

Gambar 4 menunjukkan dendogram UPGMA yang menunjukkan pola klustering dari nilai rata-rata kesamaan matrik dengan menggunakan 10 primer OPA.

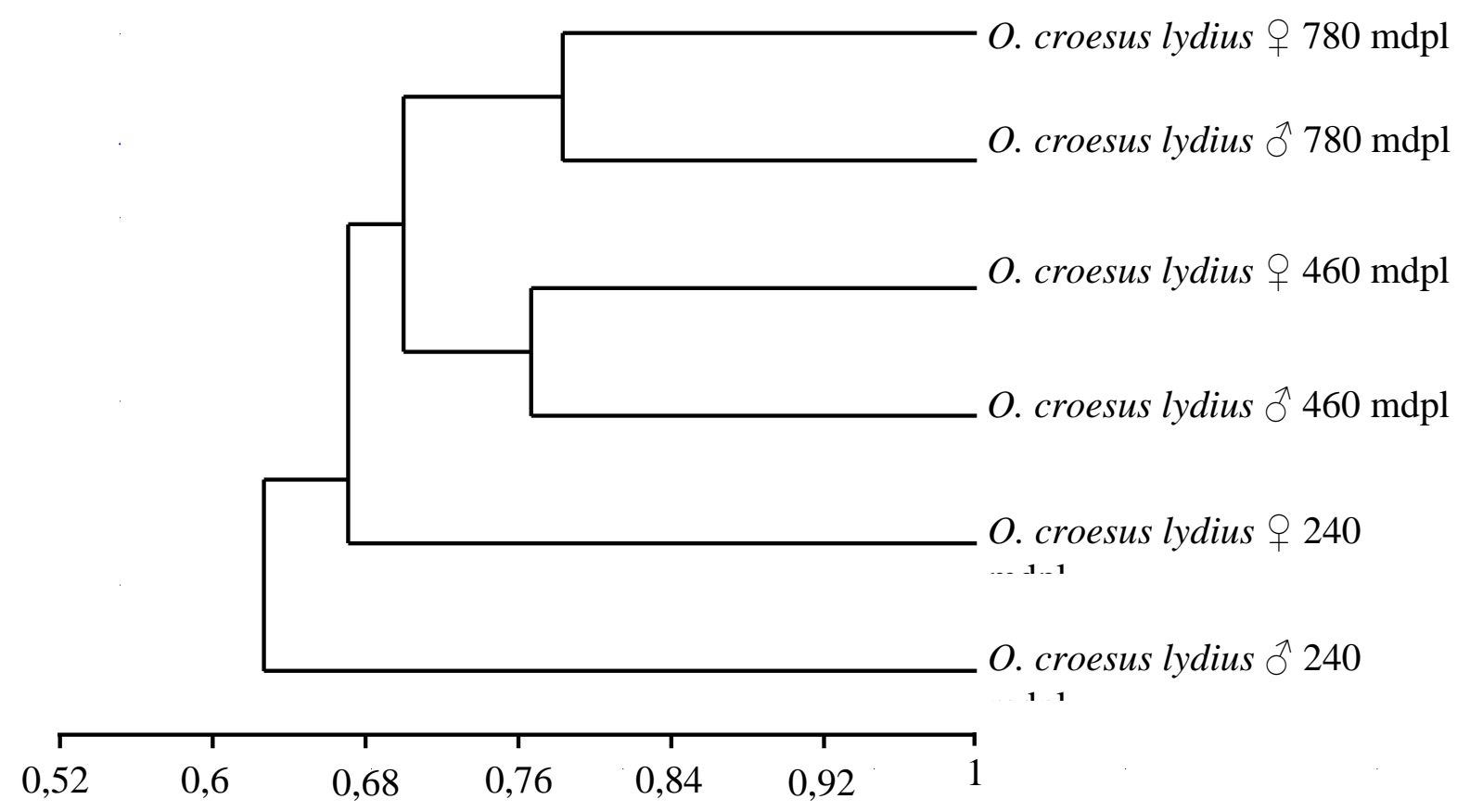

Simple Matching Coefficient

Gambar 4. Dendogram O. croesus lydius berdasarkan kehadiran pola pita DNA dianalisis dengan metode UPGMA

Hasil analisis UPGMA (dendrogram) menunjukkan bahwa terbentuk 4 kluster utama pada $O$. croesus lydius dari hotspot dengan ketinggian $240 \mathrm{~m} \mathrm{dpl}, 460 \mathrm{~m}$ dpl \& $780 \mathrm{~m}$ dpl. Pada kluster utama I dengan nilai kemiripan 0,63 pada $O$. croesus lydius jantan 240 mdpl. Pada kluster utama II dengan nilai kemiripan 0,67 yaitu pada semua $O$. croesus lydius betina dari hotspot dengan ketinggian $240 \mathrm{~m}$ dpl dan pada kluster utama III dengan 
nialai kemiripan 0,76 pada $O$. croesus lydius jantan dan betina dari hotspot dengan ketinggian $460 \mathrm{~m}$ dpl dan $780 \mathrm{~m}$ dpl. Selanjutnya pada kluster utama IV dengan nilai kemiripan tertinggi 0,78 pada $O$. croesus lydius jantan dan betina dari hotspot dengan ketinggian $780 \mathrm{~m}$ dpl.

\section{PEMBAHASAN}

Hasil penelitian ini menunjukkan bahwa terdapat pola pengelompokkan kemiripan pada kupu-kupu O. croesus lydius terbentuk berdasarkan lokasi hotspot Semakin jauh lokasi hotspot kupu-kupu O. croesus lydius maka akan memiliki kemiripan yang rendah dan sebaliknya kemiripan terbanyak pada kelompok kupu-kupu $O$. croesus lydius yang berasal dari satu lokasi hotspot. Pada analisis karakter molekuler dengan teknik PCRRAPD diketahui bahwa $O$. croesus lydius yang paling mirip terdapat pada ketinggian 780 mdpl (Tabel 4). Hasil penelitian ini menunjukkan bahwa pada habitat dengan ketinggian sama terdapat kemiripan yang tinggi pada spesies yang mendiaminya, sebaliknya pada habitat dengan ketinggian yang berbeda memiliki kemiripan yang rendah. Hal ini sejalan dengan Prakash $d k k$ (2007) yang melaporkan adanya keanekaragaman genetik pada kupu-kupu pada berbagai gradien ketinggian di India barat.

Keanekaragaman genetik pada $O$. croesus lydius kupu-kupu endemik pulau Halmahera selain dipengaruhi oleh faktor rekombinasi gen melalui perkawinan juga dipengaruhi oleh ketinggian dan daya dukung habitat, hal ini sejalan dengan hasil penelitian Hawkins (1996) di Costa Rica. Salah satu bentuk daya dukung habitat adalah ketersediaan makanan (host plant) bagi $O$. croesus lydius yaitu tanaman Mussaenda dan Asoka. Sejalan dengan penelitian Sharma dan Joshi (2009) yang menyatakan bahwa kompleksitas struktural habitat dan keragaman bentuk vegetasi berkorelasi dengan keragaman spesies kupu-kupu. Selanjutnya keanekaragaman vegetasi yang tinggi akan menyebabkan tingginya keanekaragaman kupu-kupu (Van Vu, 2011). Komponen daya dukung berupa naungan, ketersediaan air dan mineral, jenis pakan, suhu dan kelembaban (Soemarwoto,2001). Kondisi habitat berkaitan dengan ketersediaan makanan (host plant) dan jumlah individu $O$. croesus lydius yang menjadi populasi dalam habitat juga dipengaruhi oleh keadaan geografis yang berbeda dan terisolasi oleh jarak yang terpisah oleh bentang alam dan kondisi habitat dari populasi pada ketinggian ekstrim (Wibowo, 2008; Sullivan dan Miller, 2007).

Hasil penelitian ini juga menunjukkan bahwa keanekaragaman intraspesies kupu $O$. croesus lydius di pulau Halmahera masuk ke dalam kategori tinggi. Hal ini ditunjukkan oleh rendahnya nilai kemiripan. Persentase polimorfisme (pola pita) dari DNA sebesar 71,795\% menunjukkan kategori yang cukup tinggi. Keanekaragaman intraspesies pada kupu O. croesus lydius merupakan potensi sumberdaya genetik lokal yang perlu dikaji lebih lanjut sebagai dasar upaya konservasi spesies endemik yang berpotensi punah. Keanekaragaman intraspesies yang tinggi mengindikasikan bahwa komponen daya dukung yang mampu menjamin kelangsungan hidup populasi $O$. croesus lydius di pulau Halmahera sebagai kupu endemik yang memiliki nilai ekologis, edukatif dan estetika yang tinggi.

\section{KESIMPULAN}

Keanekaragaman genetik kupu-kupu endemik pulau Halmahera $O$. croesus lydius berdasarkan hasil analisis data molekuler dengan teknik PCR-RAPD menunjukkan kategori yang cukup tinggi pada aras intraspesies dengan persentase polimorfisme sebesar $71,795 \%$. Kemiripan tertinggi terdapat pada kupu-kupu $O$. croesus lydius yang berasal dari lokasi ketinggian tempat $780 \mathrm{~m}$ dpl. Pola pengelompokkan berdasarkan kemiripan terdapat pada lokasi habitat dengan ketinggian yang sama.

\section{UCAPAN TERIMAKASIH}

Penulis mengucapkan terima kasih kepada Bapak Alisi, praktisi konservasi kupu di Halmahera Selatan dan Dr. Sundari, M.Pd. yang telah mendampingi peneliti di lapangan, 
Ibu Djunijanty Peggy, M.Si. Ph.D., peneliti kupu-kupu LIPI yang telah memberikan informasi referensi ilmiah dan literatur tentang kupu-kupu di Indonesia kepada peneliti.

\section{DAFTAR PUSTAKA}

Collins NM and Morris MG. 1985. Threatened Swallowtail Butterflies of the World. The IUCN Red Data Book. IUCN, Gland and Cambridge. 440: 294-295.

Hawkins BA and Devries PJ. 1996. Altitudinal Gradients In The Body Sizes Of Costa Rican Butterflies. ACTA Oecolog. 17: 185-194.

Kovach WL. 2007. Mutivariate Statistical Package (MVSP) Plus Version 3.22 User's Manual. Publish by Kovach Computing Services. p. 137.

Leather S. 2005. Insect sampling in Forest Ecosystem. Blackwell Science Pub. Australia.

Mas'ud A dan Corebima AD. 2016. Jenis Kupu Pengunjung Bunga Mussaenda Dan Asoka Di Kawasan Cagar Alam Gunung Sibela Pulau Bacan. Prosiding Seminar Nasional Biodiversitas. UNS.

Prakash J and Arya M. 2007. Butterfly Communities Along Altitudinal Gradients in a Protected Forest in the Western Himalayas, India. Natural History Jounal of Chulalongkom University 7: 1-9 Mey 2007.

Peggie DJ. 2011. Precious and Protected Indonesian Butterlies. Jakarta: PT. Binamitra Megawarna.

Peggie DJ. 2011. Precious and Protected (Indonesian Butterlies). Kupu-kupu Indonesia yang Bernilai dan dilindungi. Diterbitkan oleh; PT Binamitra Megawarna, Jakarta, Indonesia; ISBN: 978-979-15217-4-1.

Sharma VL, Kaur P, Gill TK, Kumari M, Sobti RC. 2010. Genetic Characterisation in Two Species Of Catopsilia (Pieridae: Lepidoptera) By RAPD-PCR Technique. Journal Caryologia. vol. 63(3): 250-256.
Soemarwoto O. 2001. Atur-diri-sendiri: paradigma baru pengelolaan lingkungan hidup: pembangunan ramah lingkungan: berpihak pada rakyat, ekonomis, berkelanjutan. Gadjah Mada University Press.

Sullivan JB and Miller WE. 2007. Intraspecific Body Size Variation In Macrolepidoptera As Related To Altitude of Capture Site And Seasonal Generation. Journal of The Lepidopterists Society. vol 2: 72-77.

Tiple AD, Padwad SV, Deshmukh VP. 2010. Molecular Characterization of Morphologically Similar Four Pieridae Butterflies (Lepidoptera: Insecta) by RAPD-PCR Technique. International Journal of Pharma and Bio Sciences (IJPBS). vol 1(2): 1-7.

Van Vu L and Quang Vu C. 2011. Diversity Pattern of Butterfly Communities (Lepidoptera, Papilionoidae) in Different Habitat Types in a Tropical Rain Forest of Southern Vietnam. International Scholarly Research Network (ISRN) Zoology. ID 818545, hal 8.

Wallace AR. 1869. The Malay Archipelago. Foreword 1987, by Lioyd Fernando. Printed in Singapore. 479: 257-258.

Wibowo A, Sunarmo MTD, Makmur S, Subagja S. 2008. Identifikasi Struktur Stok Ikan Belida (Chitala spp.) dan Implikasinya untuk Manajemen Populasi Alami. Jurnal Penelitian Perikanan Indonesia. vol 14: 31-44.

Yuwono T. 2005. Biologi Molekular. Erlangga. Jakarta. hal. 258.

Zothansangi, Vanlalruati C, Kumar NS, Gurusubramanian G. 2011. Genetic Variation Within Two Cryptic Species Of Cirrochroa (Heliconiinae: Lepidoptera) By RAPD-PCR Technique. Science Vision. Journal Mipograss. 3: 165-170

Zulfahmi. 2013. Penanda DNA untuk analisis genetik tanaman. Jurnal agroteknologi. vol. 3(2): 41-52. 